\title{
Retraction Note to: Effects of HDM2 antagonism on sunitinib resistance, p53 activation, SDF-1 induction, and tumor infiltration by $\mathrm{CD} 11 \mathrm{~b}+/ \mathrm{Gr}-1+$ myeloid derived suppressor cells
}

\author{
David J. Panka ${ }^{1,3^{*}}$, Qingjun Liu' ${ }^{1,2}$, Andrew K. Geissler ${ }^{1,3}$ and James W. Mier ${ }^{1,4}$
}

\section{Retraction Note to: Mol Cancer 12, 17 (2013) https://oi.org/10.1186/1476-4598-12-17}

The Editor-in-Chief has retracted this article after an investigation by Harvard Medical School and Beth Israel Deaconess Medical Center and additional analysis by the Office of Research Integrity found:

- Reuse and relabelling of the same source bands to falsely represent different experimental results in Figure 1 (reuse of the bands in the fourth to fifth lanes of the second row representing noxa expression in the control group of A498 cell type, to falsely represent noxa expression in the sunitinib resistant group of A498 cells in the same figure, eleventh to twelfth lanes of the second row)

- Reuse and relabelling of the same source bands to falsely represent different experimental results in Figure 1 (reuse of the band in the eighth lane of the second row representing noxa expression in the third sample of the sunitinib responding group, to falsely represent noxa expression in the fifth sample of the sunitinib responding group in the same figure, tenth lane of the second row
- Reuse and relabelling of the same source bands to falsely represent different experimental results in Figure 6B (first two lanes of the bottom row representing vinculin expression in control group, and eleventh and twelfth lanes of the bottom row representing vinculin expression in dox + sunitinib group)

Andrew K Geissler and James W Mier agree with this retraction, David J Panka does not agree with this retraction. The Editor-in-Chief has not been able to find a current email address for Qingjun Liu.

\section{Author details \\ ${ }^{1}$ Division of Hematology-Oncology, Beth Israel Deaconess Medical Center and Harvard Medical School, Boston, MA, USA. ${ }^{2}$ Division of Urology, Beijing Friendship Hospital, Capital Medical University, Beijing, China. ${ }^{3} 330$ Brookline Avenue, RW-571, Boston, MA 02215, USA. ${ }^{4} 330$ Brookline Avenue, RW-563A, Boston, MA 02215, USA.}

Published online: 11 June 2021

* Correspondence: dpanka@bidmc.harvard.edu

${ }^{1}$ Division of Hematology-Oncology, Beth Israel Deaconess Medical Center and Harvard Medical School, Boston, MA, USA

${ }^{3} 330$ Brookline Avenue, RW-571, Boston, MA 02215, USA

Full list of author information is available at the end of the article

C C The Author(s). 2021 Open Access This article is licensed under a Creative Commons Attribution 4.0 International License, which permits use, sharing, adaptation, distribution and reproduction in any medium or format, as long as you give appropriate credit to the original author(s) and the source, provide a link to the Creative Commons licence, and indicate if changes were made. The images or other third party material in this article are included in the article's Creative Commons licence, unless indicated otherwise in a credit line to the material. If material is not included in the article's Creative Commons licence and your intended use is not permitted by statutory regulation or exceeds the permitted use, you will need to obtain permission directly from the copyright holder. To view a copy of this licence, visit http://creativecommons.org/licenses/by/4.0/ The Creative Commons Public Domain Dedication waiver (http://creativecommons.org/publicdomain/zero/1.0/) applies to the data made available in this article, unless otherwise stated in a credit line to the data. 